\title{
Evolution of As and groundwater isotopes along a sharp gradient in As concentrations in Van Phuc, Vietnam
}

\author{
Rolf Kipfer, Caroline Stengel \& Michael Berg* \\ Eawag, Swiss Federal Institute of Aquatic Science and Technology, Dübendorf, Switzerland \\ (*michael.berg@eawag.ch)
}

Benjamín C. Bostick \& Alexander van Geen

Lamont-Doherty Earth Observatory of Columbia University, Palisades, NY

Mason O. Stahl, Peter Oates \& Charles F. Harvey

Massachusetts Institute of Technology, Cambridge, MA

\section{Vi Mai Lan, Nguyen-Ngoc Mai, Pham Thi Kim Trang \& Pham Hung Viet Hanoi University of Science, Vietnam National University, Hanoi, Vietnam}

ABSTRACT: Van Phuc is located $15 \mathrm{~km}$ downstream Hanoi in a meander of the Red River. This site features a sharp gradient of high and low arsenic concentrations along with contrasting redox conditions. As an international research team we established a network of observation wells to tackle biogeochemical and hydrological causes of arsenic mobilization, transport and retardation. Groundwater flow points towards Hanoi where large-scale pumping is drawing high-As groundwater from Holocene aquifers to Pleistocene aquifer. Various results and aspects of on-going studies including groundwater isotopes will be presented.

Van Phuc is a candidate site for in-depth studies within the International Continental Drilling Program, involving various scientific teams from $\sim 10$ countries.

\section{INTRODUCTION}

The village of Van Phuc is located south of Hanoi and exhibits sharply contrasting groundwater As concentrations (Figure 1). Embedded in a welldefined hydrological system, this site is ideal to study the complex interplay between geochemistry and hydrology that control the magnitude of dissolved As in the aquifer (Berg et al. 2008, Eiche et al. 2008).

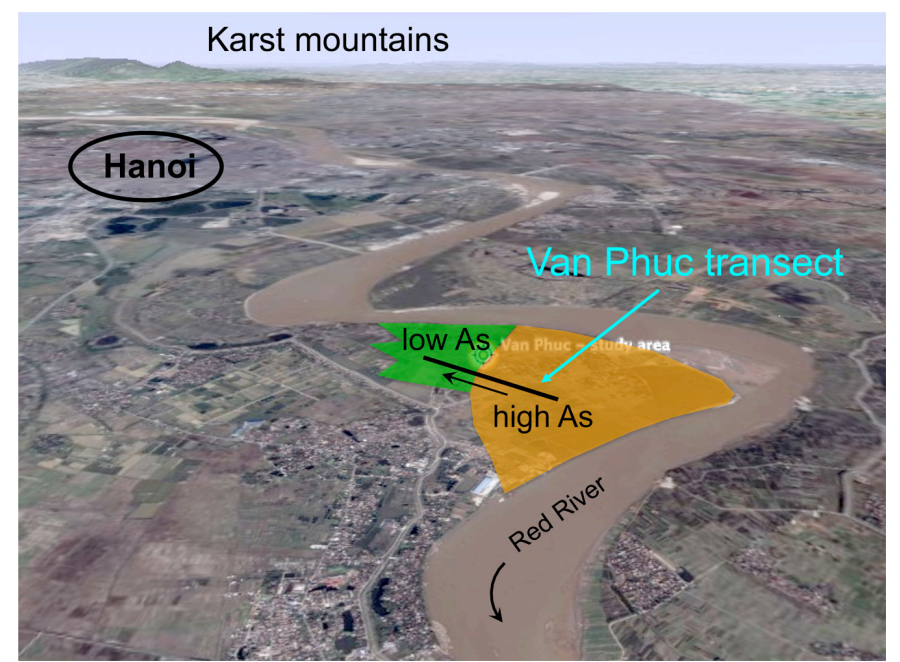

Figure 1. Bird view of the Van Phuc study site denoting the sharp contrast of high and low levels of dissolved As in the aquifer. Groundwater flow points towards Hanoi where extensive amounts of groundwater are pumped for public water supply.

\section{RESULTS}

Since 2006, we collected sediment and porewaters from $10-55 \mathrm{~m}$ depths along a $1-\mathrm{km}$ transect (Figure
2). The high resolution cross section illustrates considerable changes in arsenic concentrations and retention. The cross section was used to target specific locations to collect sediment cores and to install monitoring wells for mineralogical and biological investigations (van Geen et al. 2008, Eiche et al. 2010, Bostick et al. 2011, Al Lawati et al. 2011).

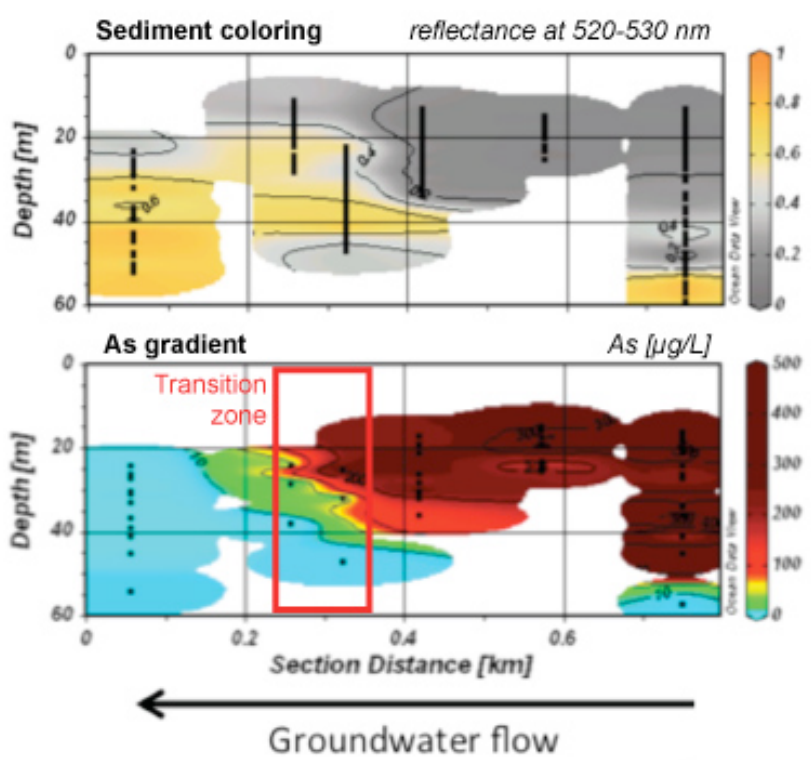

Figure 2. Cross section of sediment coloring and As concentrations along the Van Phuc transect indicated in Figure 1. The transitions zone of high to low As spans over a short distance of $<100 \mathrm{~m}$.

Besides the As and sediment reflectance shown in Figures 2, the sharp transition zone is also character- 
ized by sudden changes in dissolved $\mathrm{NH}_{4}$, DOC, $\mathrm{Mn}$, and $\mathrm{Fe}$ concentrations. And perhaps even more striking are the groundwater ages that exhibit young water converging with old water in the transition zone (Figure 3).

Groundwater dating with the ${ }^{3} \mathrm{H}-{ }^{3} \mathrm{He}$ method (Klump et al. 2006), and hydrological modeling based on long-term observations of groundwater levels in our monitoring wells, revealed that groundwater flows in north-westerly direction towards the City of Hanoi (see Figure 1) where public drinking water facilities draw $>750,000 \mathrm{~m}^{3} /$ day of groundwater from the Pleistocene aquifers that have already become As-contaminated (Winkel et al. 2011).

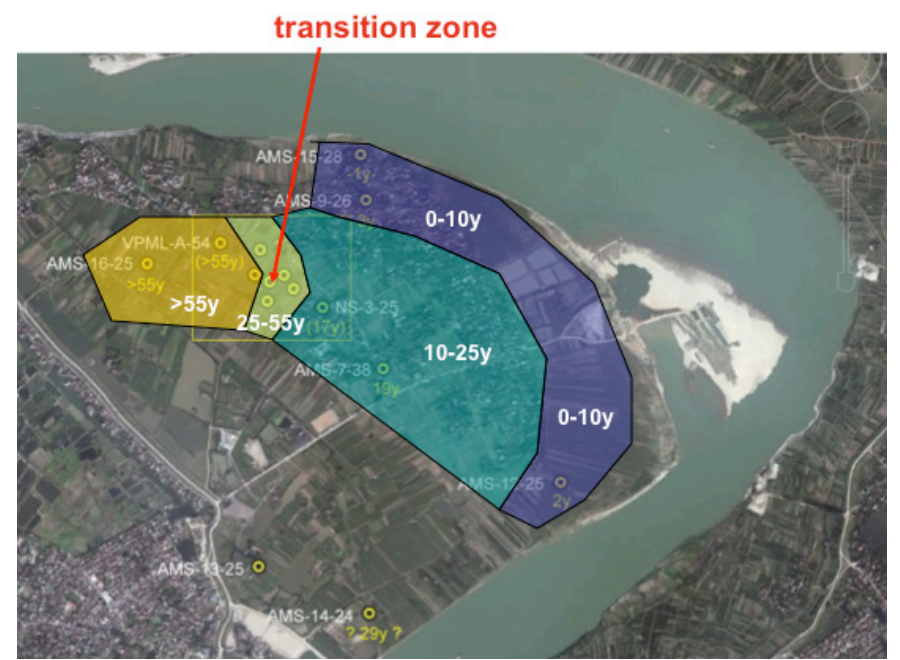

Figure 3. Areas of mean groundwater ages at the Van Phuc site featuring a pronounced gradient in age from 25 years to $>55$ years concurrent with the sudden transition in As concentrations and other groundwater parameters.

\section{OUTLOOK}

Scientific evidence gathered so far indicates that groundwater pumping in Hanoi is drawing As-laden water to formerly uncontaminated areas. The key question examined here is whether the boundary between low- and high-As aquifers within Van Phuc is shifting northward in response to increased withdrawals in Hanoi and, if so, by how much.

Our on-going studies in Van Phuc therefore have the potential to determine key parameters that are likely of general importance for any As-affected regions around the globe, such as i) to witness the intrusion of high-As groundwater from highly reducing (grey colored) aquifers to more oxic and low-As aquifers (orange colored), ii) to determine As retardation coefficients in-situ, iii) to estimate time-scales of vulnerability to future contamination of low-As aquifers, and iv) to tackle relevant biogeochemical triggers controlling As mobilization and retardation at transition fronts.

\section{References}

Al Lawati W.M., Rizoulis A., Eiche E., Boothman C., Polya D.A., Lloyd J.R., Berg M., Vasquez-Aguilar P., van Dongen B.E. Characterisation of organic matter and microbial communities in contrasting arsenic-rich Holocene and arsenic-poor Pleistocene aquifers, Red River Delta, Vietnam. Applied Geochemistry, in press. doi:10.1016/j.apgeochem.2011.09.030

Berg M., Trang P.T.K., Stengel C., Buschmann J., Viet P.H., Giger W., Stüben D. Hydrological and Sedimentary Controls Leading to Arsenic Contamination of Groundwater in the Hanoi Area, Vietnam: The Impact of Iron-Arsenic Ratios, Peat, River Bank Deposits, and Excessive Groundwater Abstraction. Chemical Geology, 249, 91-112 (2008).

Bostick B.C., Radloff K., Harvey C., Stahl M., Oates P., Lan V.M., Mai N.N., Trang P.T.K., Viet P.H., Berg M., Stengel C., van Geen A. Arsenic Mineralogy and Phase Partitioning Across a Sharp Gradient in Arsenic Concentrations in Van Phuc, Vietnam. Proceedings of Conference on Arsenic in Groundwater in Southern Asia, Hanoi, Vietnam (November 14-17, 2011), 13.

Eiche E., Kramar U., Berg M., Berner Z., Norra S., Neumann $\mathrm{T}$. Geochemical changes in individual sediment grains during sequential arsenic extractions. Water Research, 44, 5545-5555 (2010).

Eiche E., Neumann T., Berg M., Weinman B., van Geen A., Norra S., Berner Z., Trang P.T.K., Viet P.H., Stüben D. Geochemical processes underlying a sharp contrast in groundwater arsenic concentrations in a village on the Red River delta, Vietnam. Applied Geochemistry, 23, 31433154 (2008).

Klump, S., Kipfer, R., Cirpka, O.A., Harvey, C.F., Brennwald, M.S., Ashfaque, K.N., Badruzzaman, A.B.M., Hug, S.J., Imboden, D.M.. Groundwater dynamics and arsenic mobilization in Bangladesh assessed using noble gases and tritium. Environ. Sci. Technol. 40, 243-250 (2006).

van Geen A., K. Radloff, Z. Aziz, Z. Cheng, M.R. Huq, K.M. Ahmed, B. Weinman, S. Goodbred, H.B. Jun, Y. Zheng, M. Berg, P.T.K. Trang, L. Charlet, J. Metral, D. Tisserand, S. Guillot, S. Chakraborty, A.P. Gajurel, B.N. Upreti. Comparison of arsenic concentrations in simultaneouslycollected groundwater and aquifer particles from Bangladesh, India, Vietnam, and Nepal. Applied Geochemistry, 23, 3244-3251 (2008).

Winkel L.H.E., Trang P.T.K., Lan V.M., Stengel C., Amini M., Ha N.T., Viet P.H., Berg M. Arsenic pollution of groundwater in Vietnam exacerbated by deep aquifer exploitation for more than a century. P. Natl. Acad. Sci. USA (PNAS) 108, 1246-1251 (2011). 